\title{
PHILOLOGICAL SOCIETY.
}

\begin{tabular}{lll} 
Vor. V. JUNE 27, 1851. & No. 112. \\
\hline
\end{tabular}

\section{Professor KEY in the Chair.}

\author{
A paper was read- \\ "On the Dexivationand-Meaning of certain Latin Words". By \\ Professor Key \\ One of the uses to which the power of the Philological Society
} may with advantage be directed is the collection of fragmentary notices of an etymological character. Such often occur to scholars, and are lost simply because they are but fragments, and no ready place of deposit presents itself. It is much to be desired that Members of the Society should be invited to forward such chance thoughts to head-quarters, in order that they may be duly recorded. If numerous, they may together furnish a supply of food for a whole evening's consumption, and even a solitary fragment may find a fitting place at the end of a longer paper. It is proposed on the present occasion to give some unconnected suggestions of this kind on a few vocables of the Latin language.

The two verbs hiscere and hiare are commonly regarded as all but equivalents for each other in meaning, and it has been perhaps by all lexicographers assumed that they are closely related in origin. The former opinion on examination will be found to be very far from the truth, and the latter, to say the least, improbable. Thus Forcellini begins his article with giving as synonyms of hio. "hisco, aperior'; and as synonyms of hisco, 'hio, aperior.' Similarly in a popular Latin-English Lexicon, we have ' hio, to open, to open the mouth ; hence to gape, yawn, \&c.,' and 'hisco, to open, gape, be open; to open the mouth,' \&c. If a person read these two articles no farther, he would justly conclude that the two words were synonymous. The real distinction peeps out in some measure, when we find the former word translated towards the close of the article by the phrase 'to speak or utter with the mouth wide open,' while the article on hisco adds the translation ' to mutter.' In truth, the real distinction between the two words is most marked. Hiare means exclusively ' to open the mouth wide,' whereas hiscere is 'barely to separate the lips.' In the one case we have a wide abyss open before us, in the other but a narrow chink. Thus the former, hiare, is used of the crocodile, an animal distinguished from most others by the power of raising the upper jaw to a right angle with the lower. It is also employed with effect where the ghosts, in the 6th book of the झEneid, stretch wide their jaws and yet give out but a tiny sound. Again, Virgil speaks of the Leo immane hians. The same idea stands out where Juvenal tells how the rustic's child shudders at the wide-spread jaws of the pale mask-personae pallentis hiatum; where Persius talks of a ranting tragic actor-fabula

vor. $\nabla$. 
hianda tragoedo; or where Juvenal uses the similar phrase-'Grande Sophocleo carmen bacchamur hiatu.' We might also appeal to passages in which the same word happily expresses the greedy glutton ready to devour what is before him, or the idle and gaping gobemouche.

How different is it when we turn to the use of hiscere! The first passage quoted by Forcellini himself, is of the cracks in ill-seasoned wood. The third consists of the two words rima hiscit; and when we come to the use of the verb in the sense of speaking, instead of the loud bawling which hiare always denotes, we have the lowest and most indistinct muttering. We require no picking of passages to prove our point. Those quoted by Forcellini are more than enough for us : Cic. Phil. ii. 43. Respondebisne ad haec? aut omnino hiscere audebis.-Liv. vi. 16. Nec attollere oculos aut hiscere audebant.-Ov. Met. xiii. 231. Nec hiscere quidquam Ausit.-Gell. xv. 9. Cum homo vultum intorqueret et non hisceret et colores mutaret.Virg. Aen. iii. 313. vix raris turbatus vocibus hisco. Even the passage from Prop. iii. 3, 4, loses its whole spirit for him who with Forcellini would regard hiscere as a mere equivalent for loqui; and it is the more surprising that this able lexicographer should commit this error, as it might have been corrected by the next following line, Parvaque tam magnis admoram fontibus ora.

But not only are the words diametrically opposed to each other in meaning; they are also, we contend, strangers in blood. In the word hia-, as an Italian reads the word, we have a sound nearly equivalent to yaw in our own yawn, and this sound is precisely that which accompanies the act of yawning, so that it would be impossible to find a better example of the onomatopoetic principle. On the other hand, hisc of hiscere has probably a foreign element in the $c$. Such a view is in accordance with what we have asserted in former papers about the final letter in talk, walk, pluck, hark. This $c$ is the remnant, we believe, of a diminutival suffix, which appears as a whole syllable in the nouns cim-ec-, pul-ec-, cul-ec- (nom, cimex, pulex, culex). We select these words because no one will doubt the propriety of employing a word of diminutival form for the bug, the flea, and the gnat. Equally well-adapted is this suffix for our verb hiscere, if our translation of it be right. Now when the $c$ is removed from hisc-, we have the very sound his which is produced by the rapid passage of air through a narrow chink, and thus again we are supported by the principle of onomatopoeia. Lastly, it may be worth while to notice that the inceptive of liare would be, not hiscere, but hiascere, a verb which really exists.

The word reciprocus seems to deserve some notice from the neglect it has met with in the popular lexicons of the day. Lünemann, for example, is not merely silent upon its etymology, but he omits i:s ordinary sense, viz. 'ebbing and flowing as the tide'; and this although Forcellini quotes three passages from Pliny in support of this meaning. We mention this the more, because there has been of late years a disposition to disparage the great work of the Italian scholar, and unduly to exalt lexicons which have been compiled by 
Germans. The truth is that Scheller borrowed without acknowledgement from Forcellini nearly all that is of merit in his work, and added not a little of his own that is unfounded. Those German writers who have since laboured in the same department, with the exception of Freund, have for the most part avowedly taken Scheller for their basis, and the result is, that their lexicons are immeasurably inferior to that of Forcellini. But to return to our adjective reciprocus; the crude form of this word is reciproco-, and as an $i$, when employed as a connecting vowel, performs an office which was assigned to $o$ in Greek or $u$ in Old Latin, it may be well to look at the word in the shape reco-proco. 'Thus divided, the form of the word seems to suggest the question whether the two prepositions $r e$ and pro do not form the chief substance of the word; of course the main difficulty on this supposition lies in the $c$ which follows re and pro. A $d$ after these prepositions would have been sufficiently familiar, as in redire and prodire. The origin of the $d$ which is thus fond of attaching itself to prepositions, seems very uncertain; but it is the common belief that it forms no essential part of the root. 'Thus the question presents itself whether the syllable co, which appears twice over in the adjective reciproco-, may be a suffix added to euch of the prepositions, so that recus and procus should be obsolete adjectives formed from the prepositions. Anticus or antiquus and posticus, as really existing adjectives, would be effective supports of this explanation, were it not for the long quantity of the vowel which in them precedes the $c$, whereas in reciprocus we have none but short vowels. Hence we cannut but hesitate as to the derivation of this word from re and pro, although the notion of backwards and forwards is so well adapted to explain its meaning.

Casting our eyes in a different direction, we find an old phrase in our own language, at least that dialect of it which prevails in the lowlands of Scotland, which may throw light on the Latin adjective, viz. rig-and-fur, used in the same sense as our more familiar phrase ridge-and-furrow. While the earlier sense of this expression belongs to the appearance of a ploughed field, it became in course of time applied metaphorically to any surface made up of successive elevations and depressions which extended in parallel lines. Thus Jamieson's dictionary speaks of rig-and-fur as a name for thickly-ribbed worsted stockings. Elevation seems to have been the primary idea expressed in the term rig; and its use as a name for ' the back,' was perhaps at first limited to the backs of animals, in whose body it occupies the highest place. Be this as it may, all the Teutonic languages possess the rout in the sense of back. Thus we find Icelandic hrygg (nom. hrýggr), Ang.-Sax. hrieg, Dan. ryg, Old.Frisian hreg or reg. Chaucer has rigge and riggin-bone for the back-bone (or more literally back's-bone). The old Scotch writers Wallace and Douglas, according to Jamieson, have rig or ryy; and Robert of Gloucester with a change of vowel rug. . This prepares us for the German rück, which is a provincial term in the sense of back or ridge, and is the essential syllable of rïcken, 'back,' to say nothing of riick as an ordinary prefix, and the adverb zurück. Again, it will of course be 
admitted that ridge is immediately connected with our obsolete substantive rig. Nay, even in ridge, as applied to a line of hilly country, we have but a translation of dorsum montis.

We next turn to the second element in rig-and-fur, or ridge-andfurrow. Fur, as a single word, has disappeared from our language; but we should not have doubted that it once existed, even if our evidence had been confined to the word furrow, for in the syllable $o w$ we have evidently nothing but a suffix, and in fact one of diminutival power. The substantive sparrow, for example, consists of an element sparr with the suffix in question, while the first syllable is identical with that of sper-ling, the German name for the same bird. It has been again and again noticed that this suffix ow corresponds to one which takes a guttural form in allied languages. It is scarely necessary to quote in proof the well-known pairs of words, talg Germ. and tallow, galg-en and gallows, sorge and sorrow, mark and marrow. Similarly to the English furrow corresponds the German furche. But the simple word still exists in the Danish fure, ' a furrow.'

We now proceed to compare the expressions rig-and-fur or ridgeand-furrow with the Latin reciprocus. The difficulty, that in theLatin word we find no representative of our copulative particle, is at once disposed of by the well-known fact that the Latin language deems it enough to place opposed words in mere juxtaposition. Thus hac illac, 'this way and that,' is more idiomatic than hac atque illac. Secondly, the English substantive furrow* is accurately represented by the Latin porca, ' a furrow," the $f$ in the former tongue as usual corresponding to a $p$ in the latter, and $o w$, as was to be expected, taking the form of a guttural, while the meanings are identical. Nor will any etymologist be stopped by the accident, that in reci-procus we have pro in lieu of por, seeing that the liquid $r$ is notorious for the habit of transposition with its adjoining vowel. The preposition pro itself shows this, when we compare its ordinary form with that which it takes in porrigo, porgo, polliceor, pollingo.

But after all may not both etymologies be true? Our old substantive rig, 'a back,' and the Latin inseparable preposition re, 'back,' have so much in common as regards both form and meaning, that one can scarcely get rid of the belief that they must be connected. Although elevation be the prevailing notion when we look at the back of a quadruped, the back of the erect animal, man, introduces a new relation, which an Englishman expresses in the idea of 'going back or looking back,' and a Roman by the little words re and retro. Then as to form, it is a matter of no great

* If confirmation be needed, we have it in the pair of words, porcus, Lat., and farrow, Eng.; and it may be noticed that porcus again possesses a diminutival suffix, being a derivative of por (Lucipor, Marcipor) or puer. Exactly in the same way juvencus, 'a bullock,' and juvenca, 'a heifer,' are derivatives from juvenis. Mooxos too must owe its various meanings of "bullock, heifer, boy, girl, young bird, young shoot," to a similar cause. It may be objected to our derivation of porcus from por, 'a boy,' that analogy would require us to find a primitive of similar meaning in the first part of farrow. We admit this, and point to the Danish fyr, "a youth, a young man." 
importance whether re having lost a final guttural be a corruption of an older form rec, or on the other hand reci or reco be a derivative from a simpler stem $r e$. In fact, there is scarcely a more difficult problem to solve than the claim to primogeniture between two alleged stems, which appear, one as a consonant followed by a vowel, and the other in triliteral form, viz. a vowel between two consonants. We refer to such stems as $\phi \alpha$ and $\phi \alpha \nu$ of $\phi \alpha o s$ and $\phi a \iota \nu \omega ; \beta \alpha$ and $\beta a \nu$ of $\epsilon \beta \eta \sigma a$ and $\beta a \iota \nu \omega ; b u$ and $b i b$ of imbuo and bibo; le and lin of deleo and lino. Thus to take examples as parallel as may be, no one will doubt that re of reor corresponds to our old verb reck, whence the derivatives reckon and reckless; but who will say whether the guttural, as the English has it, is or is not an original element of the word? Again, who shall decide between ne, 'not,' and nec, 'not,' as seen in the phrase nec-mancipi ?

Moreover reciprocus will not be the only Latin word which contains the element reco in its longer form. We find the very word in the compound recuperare or reciperare, which Forcellini boldly, and we think justly, regards as a compound of parare and some such preposition as reci. It seems indeed at first sight as though reciperare must be a secondary form of recipere, and the present writer has elsewhere too hastily assumed the truth of such derivation; but he is now satisfied that this doctrine is erroneous. At any rate no argument in its favour can be drawn from such verbs as volnerare, pignerari, onerare, which evidently obtain the syllable er from the final syllables of the neuter substantives volnes-(volner-is), pignes-, ones-, while liberare owes the same syllable to the adjective liber. The change of $a$ to $e$, which is seen in reciperare, has its parallel in the compounds im-perare and se-perare, the latter of which coexists with separare. Forcellini justifies the lengthened form of reci for re by the examples concipilare for compilare and incitega for intega; but these words are of too doubtful a character, and rather need support themselves than have any to lend to other words.

But can porca, 'a furrow,' have any connexion with the preposition pro? Or looking to the German tongue, we may ask whether there be more than an accidental identity of form between the first three letters of furche and fur? Undoubtedly pro or porro, "forward,' is an exact antithesis to re or retro, 'backward,' just as ridge or elevation is to furrow or depression. But the awkward point is, that pro seems to represent projection rather than recession, and so to be anything but synonymous with furrow. It is some answer to this that the two ideas really do change places with each other when we change the point from which we view them. What is a salient angle when referred to a point outside a polygon, is a receding angle referred to a point within the polygon; and vice versa. So in ploughed land, a ridge denotes a projection when measured from within the earth, but a recession in reference to the human eye looking down upon it. And indeed it is only thus that we can account for the fact, that with the Romans themselves porca at last reversed its meaning and came to signify the ridge or elevated earth instead of the depressed furrow. So also in German, according 
to Campe: "Die von der Pflugschar aufgeworfene Erde, die eine eben so lange Erhöhung ausmacht, als die Furche eine Vertiefung ist, wird von Einigen auch die Furche genannt."

We would propose then the following solution of the difficulty : that porca, 'a furrow,' is a derivative from an obsolete Latin verb having for its stem per or por, and signifying to pierce or cut, in fact the analogue of the Greek $\pi \epsilon \iota p \omega$. From this verb we would deduce the preposition per, 'through,' and also the preposition pro in its sense of advancing, or forward. To pierce or cut the ground is to $\mathrm{dig}$, and thus we arrive at porca, a trench or furrow. Again, while the idea of piercing may perhaps be seen in por-ta, ' a gate,' so that of cutting gives us both por-tion (nom. portio) and par-ti-(nom.pars). We have omitted to notice, that to pass from mere alternate motion to that which produces the mark of a zigzag, we have only to add a slight lateral movement.

We turned to Lünemann to see what his theory about the origin of recuperare might be, but without profit. Under recupero he refers us to recipero, and under recipero he refers us back to recupero. On the derivation of the verb not a word.

The verb recuperare naturally reminds one of vituperare. This also with Forcellini we regard as a compound of parare. The first syllable is justly deemed to be connected with vitium, but it seems an error to suppose that that very word has entered into the formation of the verb. A neuter noun in ium is generally deduced from a verb, as gaudium, studium, imperium; and the temptation to assume an obsolete verb vit-, 'bend,' is strengthened into a conviction that such a verb really existed, by the forms vit-ex, ' a tree of the willow-kind,' by the adj. vit-ilis, 'easy to bend, made of osiers,' by vit-ta, ' a band,' by the Greek Fir-ea, and by our own words wind (the verb) and withy. Many of the words connected with this root are formed as from a verb vi-, 'bend': as vi-men, ' an osier,' vi-tor, 'a basket-maker,' vi-ti-s, ' a vine.' Now this verb would also readily form a participle or adjective vito- (nom. vitus), which would signify 'bent,' and so ' crooked.' Such an adjective we believe to form the first element of vitu-perare; and for the original meaning of the word we with some confidence propose, either ' to take in a wrong sense,' ' to mistake,' or else 'to make wrong, spoil, vitiate,' as in the Casina of Plaut. ii. 6. 58: Cur omen mihi vituperat? In either case from a secondary sense 'make out to be wrong,' we easily proceed to the notion of 'to blame.'. The verb viti-litiga-, ' to act as a pettifogging lawyer,' whence vitiligator in Pliny is an excusable abbreviation for viti-litiga-tor, seems formed with the same prefix, as also viti-lena* in Plautus; and still more clearly is this prefix seen in viti-magistratu-s, 'a magistrate unduly elected,' if Gruter be right in ascribing this word to the fragments of Sallust, as he does ad Plaut. Mostel. i. 3. 56. If this prefix be deemed to be fairly established by the evidence here produced, it must be regarded as an equivalent in meaning of the prefix mis, so familiar in our own

* It is not unlikely that len-a- and len-on-had originally a meaning not of evil import, such as 'dealer' or 'trader.' 
tongue. Now it is remarkable that this prefix is of very common occurrence, not merely in the Teutonic languages, as for instance the German miss-billigen, miss-brauchen, missethat, \&c., but also in those descended from the Latin, as the French and Italian. It would therefore be a very strange fact if it was not found in the Latin also. We would therefore suggest that our Latin prefix vito- is the representative in form as well as meaning of the Italian mis as seen in mis-contento, mis-credere, mis-leale, mis-fatto, \&c. That the letters $m$ and $w$ (for the Latin $v$ was a $w$ ) readily interchange will be here assumed as a matter proved (see vol. iv. p. 27; and on the parallelism of words in which an $m$ and $v$ or $w$ correspond to each other, see vol. iii. p. 172).

The word vesica is passed over by Forcellini and Lünemann without remark as regards its origin. Report tells us that a gentleman at Edinburgh, not however a Scotchman, seriously proposed a 'wee sack' as the real explanation of the word; but we shall not stop to discuss this etymology. The first step in all such inquiries is to ascertain the right mode of spelling a word. Now Lachmann, in his new edition of Lucretius (vi. 130), gives the reading "cum plena animae vensicula parva saepe det haut parvum sonitum displosa repente." In his note on this passage he quotes the authority of Caper (Putsch. 2246) for the orthography vensica, and at the same time adds, that de vensica is the reading of the Putean MS. of Martial, xiv. 62. The moment we see the word thus written we are reminded of the word vento- (n. ventus), for the connexion between a bladder and wind is familiar enough, and indeed bas already been seen in the preceding quotation from Lucretius. Caper too supports his mode of writing the word by the argument quonian non est sine ventn. But the matter, if yet doubtful, seems decided by the fact that the German blase, with which our own bladder is connected, is immediately related to the German verb blasen, 'to blow.' We would observe too that ventouse, the French for a cupping-glass, is known to be derived from the fem. adjective ventosa. Now ven-sica has also the appearance of a fem. adjective, equivalent to ven-tiva, which would come from the obsolete verb ven-, 'blow,' precisely as cap-tivo- from cap-, 'talse.' For the change of $s$ and $t$, compare pulsare, mersare, with the older forms pultare, mertare; and for that of $c$ and $v$, nix nivis, vivo vixi, focus foveo, ascripticius and ascriptivus (see also vol. iii. p. 209). An olsolete

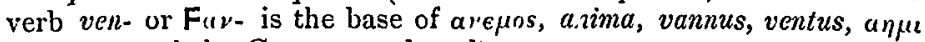
and $a \eta p$, and the German verb weh-en.

The verb patrare, if we have sufficient faith in etymology to deduce its meaning from its form, ought to signify ' to create a father,' just as albare is 'to make white.' But as this translation implies an inversion of the laws of nature, in its strict sense it is inadmissible. The objection however is not of force against a metaphorical usage of the word, and in fact it is an annual practice at the colleges of Cambridge for the authorities to appoint a father, that is an officer, who, as representing the college, shall go up with the candidates for a bachelor's degree, and present his young family to the Vice-chan- 
cellor. Now we find that something of the same kind was done at Rome. When the state had occasion to declare war, or to make a peace abroad, the rule, as is well known, was to commission four members of the Fetial college to act in the name of the state, and one of these was placed at the head of the commission under the title of pater patratus. 'This phrase, by its very construction, tells us that patrare was a transitive verb, and primarily signified, as we said above, to appoint a person as father. Thus Lünemann is wrong in giving to patrare as its first meaning, "Vater seyn, den Vater spielen." The latter of these two phrases, "to play the father,' i.e. 'act as father,' should strictly have been denoted by a reflective verb patrari, in agreement with medicari, ancillari, graecari, bacchari; but we are ready to admit that verbs of this class often in a subsequent stage dropped the reflective form. Thus eventually patrare came to signify to act as a pater patratus, and this even with the construction of an accusative. Hence patrare jusjurandum, in Liv. i. 24, is to take an oath, as pater patratus to abide by a treaty. From this, by an easy metaphor, the verb came into use in the sense of performing the final part in any grave act, where the agent was no longer the pater patratus; for example, p. pacem, Liv. xliv. 25, " to conclude a peace ;" p. bellum, Sal. Jug. 78, Vell. ii. 79 and 123; Tac. Ann. ii. 26, " to put the finishing stroke to a war." So far we. have the verb in connection with the very notions for which it was at first employed; but its final use was much wider, and extended to any deeds, whether good or bad, if of a serious nature. It is perfectly in accordance with this view that we find patrante ocello, " with a solemn eye,' applied to an affected reciter of a grande aliquid quod pulmo animae praelargus anhelet. Why the German editor Plum should attribute to this verb patranti, as here used by Persius, 'sensus venereus,' we do not see; nor indeed what authority Lünemann had for translating the verb in this passage by 'throwing a fatherly or affectionate look upon a person' (väterliche oder liebevolle Blicke auf jemand werfen). But in truth Lünemann seems, throughout his article on patro, to have gone astray. His second head is: 'by such (fatherly) look to obtain anything from a person; hence to carry through, fulfil, bring to pass' (durch solche Blicke etwas von jemand erlangen; daher durchsetzen, vollbringen, zu Stande bringen), 'promissa Cic., pacem Liv. \&c.'; and only at the end of the article does he arrive at the word as applied to the office of the pater patratus. Surely from such an inversion of the meanings he might have been diverted by the mere consideration that there is anything but a connection between a father's coaxing eye as telling upon a child, and the solemn duties of a state ambassador; and after all, his sole authority for the 'väterliche Blicke' is his mistranslation of Persius's patranti ocello. It should be observed too, that he quietly carries over the notion of this ocello into the other passages where there is no trace of such an idea. 